\title{
A new class of fractional type set-valued functions
}

\author{
ALEXANDRU ORZAN
}

\begin{abstract}
.
The so-called ratios of affine functions, introduced by Rothblum (1985) in the framework of finitedimensional Euclidean spaces, represent a special class of fractional type vector-valued functions, which transform convex sets into convex sets. The aim of this paper is to show that a similar convexity preserving property holds within a new class of fractional type set-valued functions, acting between any real linear spaces.
\end{abstract}

Acknowledgements. This work was supported by a research fellowship STAR-UBB, granted by Babeş-Bolyai University, Cluj-Napoca. The author wish to thank his supervisor, professor Nicolae Popovici, for suggesting the definition of set-valued ratios of affine functions in order to generalize some results known in the literature for vectorvalued functions.

\section{REFERENCES}

[1] Aubin, J.-P. and Frankowska, H., Set-Valued Analysis, Birhäuser, Boston, 1990

[2] Bhatia, D. and Mehra, A., Fractional programming involving set-valued functions, Indian J. Pure Appl. Math., 29 (1998), 525-539

[3] Berge, C., Topological spaces including a treatment of multi-valued functions, vector spaces and convexity, Oliver \& Boyd, Edinburgh-London, 1963

[4] Cambini, A. and Martein, L., Generalized Convexity and Optimization: Theory and Applications, SpringerVerlag, Berlin, 2009

[5] Das, K. and Nahak, C., Set-valued fractional programming problems under generalized cone convexity, Opsearch, 53 (2016), No. 1, 157-177

[6] Deutsch, F. and Singer, I., On single-valuedness of convex set-valued maps, Set-Valued Anal., 1 (1993), 97-103

[7] Göpfert, A., Riahi, H., Tammer, C. and Zălinescu, C., Variational Methods in Partially Ordered Spaces, Springer-Verlag, New York, 2003

[8] Khan, A. A., Tammer, C. and Zălinescu, C., Set-Valued Optimization: An Introduction with Applications, Springer, Heidelberg, 2015

[9] Nikodem, K. and Popa, D., On single-valuedness of set-valued maps satisfying linear inclusions, Banach J. Math. Anal., 3 (2009), 44-51

[10] Rothblum, U.-G., Ratios of affine functions, Math. Programming 32 (1985), No. 3, 357-365

[11] Schaible, S., Bicriteria quasiconcave programs, Cahiers du Centre d'Etudes de Recherche Oprationnelle, 25 (1983), 93-101

[12] Stancu-Minasian, I.-M., Fractional programming. Theory, methods and applications, Mathematics and its Applications, Kluwer-Dordrecht, 409 (1997)

[13] Tan, D.-H., A note on multivalued affine mappings, Studia Univ. Babeş-Bolyai Math., Cluj-Napoca, 33 (1988), 55-59

Received: 27.07.2018; In revised form: 21.12.2018; Accepted: 30.12.2018

2010 Mathematics Subject Classification. 54C60, $26 \mathrm{~B} 25$.

Key words and phrases. Affine set-valued function, ratio of affine functions, convexity preserving functions. 
BABEŞ-BOLYAI UNIVERSITY

FACUlTy OF MATHEMATICS AND COMPUTER SCIENCE

KOGĂLNICEANU 1, 400084, CLUJ-NAPOCA, ROMANIA

Email address: orzanalexandrudyahoo.com 